\title{
MODEL PEMBELAJARAN EKONOMI SYARI'AH MELALUI CTL PADA JURUSAN PENDIDIKAN EKONOMI UNIVERSITAS NEGERI SURABAYA
}

\author{
Yoyok Soesatyo \\ Jurusan Pendidikan Ekonomi, Universitas Negeri Surabaya \\ E-mail: yoyoksoesatyo3@gmail.com
}

\begin{abstract}
The Purpose of this research is to describe the concept of syari'ab economics as a comprehensive learning model for student in Surabaya state university majoring in to be economics education, to be able to describe, connect with reality or phenomena and interpret the solutions of the phenomenon that exist in the community based on syari'ab economy. The method that used in this research is descriptive research method that describes the result of the research which obtained from the respondents and field observations both from primary and secondary data. The finding in this research indicate that understanding of the Islamic economis material given by using direct instructional model is still less than the standard of competencespecified, therefore it is necessary efforts to increase the understanding material through appropriate learning model in this study is a CTL (Contectual Teaching Learning).
\end{abstract}

Keywords: Learning, Syari'ah Economics; Contectual Teaching Learning, Economics Education.

\begin{abstract}
Abstrak
Penelitian ini bertujuan mendeskripsikan model pembelajaran ekonomi syariah secara komprehensif pada mahasiswa Jurusan Pendidikan Ekonomi Universitas Negeri Surabaya, agar mampu menggambarkan, mengbubungkan dengan realitas/fenomena yang terjadi dan menafsirkan pemecahannya terhadap fenomena yang ada di masyarakat berdasarkan ekonomi syari'ah. Metode penelitian yang digunakan adalab metode deskriptif guna mendiskripsikan hasil penelitian yang diperoleh dari responden dan observasi lapangan baik yang bersumber dari data primer maupun sekunder. Temuan dalam penelitian ini menunjukkan
\end{abstract}


bahwa pemahaman materi ekonomi syari'ah yang diberikan dengan menggunakan model pembelajaran langsung masib kurang dari standar kompetensi yang ditetapkan, oleh karena itu perlu upaya peningkatan pemahaman materi melalui model pembelajaran yang sesuai dalam pembelajaran ini adalah CTL (Contectual Teaching Learning).

Kata kunci: Pembelajaran, Ekonomi Syari'ah, Contectual Teaching Learning, Pendidikan Ekonomi.

\section{Pendahuluan}

Pembelajaran ekonomi syari'ah merupakan salah satu mata kuliah pada Jurusan Pendidikan Ekonomi Universitas Negeri Surabaya. Adapun standarisasi kompetensinya adalah, pertama bertujuan agar mahasiswa memiliki kemampuan memahami konsep dasar ekonomi syariah, sumber ekonomi syari'ah, sistem ekonomi syari'ah, mikro dan makro ekonomi syari'ah, prinsip transaksi dalam ekonomi syari'ah, dan etika ekonomi syari'ah. Sedangkan standard kompetensi kedua yaitu, mahasiswa memiliki kemampuan memahami lembaga keuangan syari'ah, perbedaan lembaga keuangan syari'ah dengan lembaga keuangan konvensional, produk dan jasa dalam perbankan syari'ah, bentuk dan operasional lembaga keuangan mikro syari'ah, serta manajemen dalam lembaga keuangan syariah. Ekonomi syari'ah tidak akan pernah mencapai kesuksesan, bilamana kegiatannya berjalan dalam suatu aturan yang tidak seiring dengan ekonomi Islam.

Berbagai macam fenomena yang terjadi dalam kehidupan masyarakat antara lain kesenjangan sosial yang makin tinggi dan beban hutang yang bertambah membebani rakyat yang sangat mendambakan hadirnya suatu sistem yang dapat mengakhiri berbagai fenomena tersebut. Sementara untuk mensosialisasikan konsep ekonomi syari'ah untuk menyiapkan sumber daya manusia hanya terbatas dalam ruang lingkup kegiatan seminar, pelatihan, dan diskusi panel.

Fenomena yang terjadi saat ini, mengakibatkan banyak orang mengharapkan agar sistem ekonomi Islam hadir sebagai salah satu wacana agar dapat mengakhiri fenomena tersebut. Kondisi ini disadari atau tidak merupakan dampak dari depresiasi penggunaan sistem yang masih merujuk pada aturan-aturan konvensional. Ekonomi Islam merupakan suatu ilmu yang dasar hukumnya berbeda 
dari ekonomi konvensional, dari sumber hukum ini menyebabkan ilmu ekonomi ini disebut ekonomi Islam yang menimbulkan arti "sebuah ilmu didasarkan Al-Qur'an dan Al-Hadits". Jadi, kata Islam sebagai syarat suatu perilaku manusia, dalam memenuhi kebutuhan didasarkan atas pedoman ekonomi Islam.

Menurut Sudarsono (2002:11) bahwa dalam ekonomi Islam kebutuhan manusia terbatas, hal ini karena pemenuhannya disesuaikan dengan kapasitas jasmani manusia. Sedangkan sumber daya tidak terbatas, Allah menciptakan alam semesta bagi manusia tidak akan habis, karena di alam semesta terdapat potensi kekayaan yang sepenuhnya belum tergali oleh manusia. Oleh sebab itu, manusia dituntut untuk menggali kekayaan alam yang tidak ada batasnya secara kreatif.

Tujuan akhir ekonomi Islam adalah sebagaimana tujuan dari syariat Islam itu sendiri (maqashid asy syari'ab), yaitu mencapai kebahagiaan di dunia dan akhirat (falab) melalui suatu tata kehidupan yang baik dan terhormat (hayyah thayyibab). Inilah kebahagiaan hakiki yang sangat diinginkan oleh manusia, bukan hanya kebahagiaan semu yang seringkali pada akhirnya justru hanya melahirkan penderitaan dan kesengsaraan. Ekonomi Islam tidak hanya sekedar bereorientasi untuk pembangunan fisik material dari individu, masyarakat, dan negara saja, tetapi juga memperhatikan aspek-aspek lain yang juga merupakan elemen penting bagi kehidupan yang sejahtera dan bahagia (P3EI, 2011: 54). Secara sederhana, karakteristik ekonomi Islam dapat ditunjukkan dalam sebuah gambar sebagai berikut:

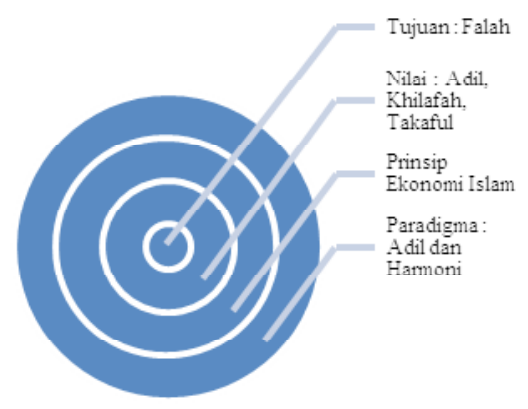

Gambar 1.

Karakteristik Ekonomi Islam (Sumber: P3EI UII Yogyakarta) 
Berdasarkan gambar di atas, menunjukkan bahwa ekonomi Islam dibangun secara hierarkis dan intergartif. Artinya, perekonomian Islam bukanlah hanya sekedar bentuk perekonomian yang adil dan harmonis, namun keadaan ini dibangun atas spirit dasar untuk mewujudkan falab yang kemudian diinternalisasikan dalam bentuk nilai-nilai dan prinsip ekonomi Islam. Kesesuaian antara tujuan (falab), nilai-nilai Islam, prinsip ekonomi, dan paradigma ekonomi Islam adalah suatu keharusan.

Sikap rasional Islami memotivasi setiap pelaku ekonomi untuk mencari informasi yang akurat agar dapat meraih falah. Informasi pada dasarnya berasal dari dua sumber, yaitu fakta empiris (ayat kauniyah) dan pemberitahuan langsung dari sang pencipta alam semesta (ayat quliyah). Syari'ah Islam berfungsi sebagai salah satu sumber informasi, sebab merupakan sumber informasi yang secara langsung diberikan oleh Allah SWT yaitu melalui Al-Quran dan sunnah. Manusia sangatlah terbatas kemampuannya dalam memahami fenomena sosial, sehingga informasi yang bersumber langsung dari Allah lah yang lebih sempurna. Inilah fungsi syari'ah Islam yang pertama. Fungsi yang kedua adalah memberikan kontrol terhadap perilaku manusia agar terselamatkan dari tindakan yang merugikan yaitu menjauhkan dari falah. Dalam hal ini syari'ah lebih dikenal sebagai fiqh atau hukum Islam yang berisikan kaidah yang menjadi ukuran, tolak ukur, pedoman yang dipergunakan untuk menilai tingkah laku manusia.

Atas dasar pengertian tersebut, kebutuhan terhadap sumber daya manusia unggul dalam kegiatan perekonomian sangat membutuhkan tenaga yang profesional. Kebutuhan itu pula yang membuat dunia pendidikan khususnya diperguruan tinggi untuk membuka mata kuliah atau program studi yang mempelajari pengetahuan dan keahlian ekonomi syari'ah. Mahasiswa Jurusan Pendidikan Ekonomi Universitas Negeri Surabaya diharapkan memiliki beberapa standard kompetensi sesuai silabus yang ada. Standar kompetensi yang pertama, antara lain: 1) Kemampuan memahami hakekat dan sejarah ekonomi syari'ah; 2) Kemampuan memahami fondasi dan sumber hukum ekonomi syari'ah; 3) Kemampuan memahami filosofi ekonomi syari'ah; 4) Kemampuan memahami dan menganalisis sistem ekonomi syari'ah; 5) 
Kemampuan mendeskripsikan, menganalisis dan mensintesakan harta dalam perspektif syari'ah; 6) Kemampuan memahami dan menganalisis akad/transaksi dalam ekonomi syari'ah; 7) Kemampuan memahami dan menganalisis prinsip jual beli, bagi hasil dan pembiayaan dalam transaksi ekonomi syari'ah; 8) Kemampuan memahami teori ekonomi mikro dan makro dalam ekonomi syari'ah; 9) Kemampuan memahami dan menganalisis etika ekonomi syari'ah (Buku Pedoman Universitas Negeri Surabaya, 2013:211).

Tujuan pembelajaran ekonomi syari'ah yang di dalamnya ada unsur pendidikan ekonomi Islam, mempunyai tujuan yang amat penting dalam kehidupan bermasyarakat, berbangsa dan bernegara. Tujuan tersebut terkait dengan upaya mewujudkan pelaku-pelaku sosial ekonomi yang memiliki karakteristik dimensi personal (seperti berbudi luhur, jujur, bekerja keras, berdisiplin, mandiri), dimensi sosial dan ekonomi (seperti kepedulian, kesetiakawanan sosial, saling menghargai, toleransi, cinta tanah air, rasa kebangsaan, jiwa kewirausahaan, hidup hemat dan sehat, memanfaatkan peluang usaha, mengenal skala prioritas dalam kehidupan, berani mengambil resiko), dimensi spiritual (iman dan taqwa), dimensi intelektual (kecerdasan, terampil, kritis, kreatif, tanggung jawab, dan semangat untuk maju). Pembelajaran ekonomi syari'ah yang mengandung berbagai nilai itu sangat penting dalam menopang pendidikan karakter bangsa yang bernuansa Islami.

Standar kompetensi kedua, yakni; 1) Kemampuan memahami perkembangan lembaga keuangan syari'ah; 2) Kemampuan memahami perbedaan lembaga keuangan syari'ah dan konvensional; 3) Kemampuan memahami riba, bunga, dan institusi bagi hasil; 4) Kemampuan memahami dan menganalisis sistem perbankan syari'ah; 5) Kemampuan mendeskripsikan dan menganalisis produk dan jasa dalam perbankan syari'ah; 6) Kemampuan memahami dan menganalisa IDB dan perkembangan Bank Islam di tingkat internasional; 7) Kemampuan memahami dan menganalisis tentang keberadaan dan operasional BPR syari'ah; 8) Kemampuan memahami dan menganalisis keberadaan dan operasional pegadaian syari'ah; 9) Kemampuan memahami dan menganalisis keberadaan dan operasional BMT; 10) Kemampuan memahami dan menganalisis keberadaan dan operasional asuransi syari'ah; 11) Kemampuan 
memahami dan menganalisis keberadaan dan operasional pasar modal syari'ah, dan yang terakhir; 12) Kemampuan memahami manajemen lembaga keuangan syari'ah (Buku Pedoman Universitas Negeri Surabaya, 2013: 212).

\section{Model Pembelajaran}

\section{Pembelajaran}

Pembelajaran merupakan suatu proses terjadinya kegiatan belajar yang dilakukan dosen dan mahasiswa dalam mencapai tujuan pembelajaran (Pendidikan Ekonomi, 2009:7). Di dalam proses pembelajaran terdapat model yang digunakan oleh dosen yaitu model pembelajaran langsung.

\section{Model Pembelajaran Langsung}

Pengajaran langsung identik dengan pengajaran ceramah. Dalam prakteknya, sangat bergantung pada kemampuan dosen dalam mengelola pembelajaran. Model pembelajaran langsung ditransformasikan langsung dari dosen kepada mahasiswa. Penyusunan waktu yang digunakan untuk mencapai tujuan pembelajaran harus seefisien mungkin sehingga dosen dapat merancang dengan tepat waktu yang digunakan.

Menurut Nur (2011: 17) model pembelajaran langsung adalah sebuah model yang berpusat pada dosen yang memiliki lima langkah: mempersiapkan dan memotivasi mahasiswa, menjelaskan dan atau mendemonstrasikan, latihan terbimbing, umpan balik dan latihan lanjutan. Model pembelajaran langsung memerlukan persiapan yang seksama dari dosen dan sebuah lingkungan belajar yang berorientasi pada tugas.

\section{Contextual Teaching and Learning (CTL)}

Pembelajaran kontekstual pertama-tama di Amerika diusulkan oleh John Dewey, pada tahun 1916. Dewey mengusulkan suatu kurikulum dan metodelogi pengajaran yang dikaitkan dengan minat dan pengalaman siswa (Trianto, 2009:105). Sedangkan Riyanto (2009:112) yang mendefinisikan CTL dengan menyebutkan posisi siswa yaitu, pembelajaran konstektual (CTL) merupakan konsep 
belajar yang membantuk guru mengaitkan antara materi yang diajarkannya dengan situasi dunia nyata siswa dan mendorong antara pengetahuan yang dimilikinya dengan penerapannya dalam kehidupan mereka sebagai anggota keluarga dan masyarakat. Riyanto juga mengatakan bahwa, sebuah kelas dikatakan menggunakan pendekatan CTL jika dalam proses belajar mengajarnya menerapkan tujuh komponen utama pembelajaran konstektual yaitu konstruktivisme (constructivism), inkuiri (inquiry), bertanya (questioning), masyarakat belajar (learning community), pemodelan (modeling), refleksi (reflection), penilaian sebenarnya (authentic assessment). (Riyanto 2009:114)

\section{Strategi Konsep Belajar Islami}

Ekonomi Islam merupakan manifestasi ajaran Islam dalam perilaku ekonomi, baik dalam penentuan tujuan kegiatan ekonomi, sikap, analisis, dan respon terhadap fenomena sosial. Dalam tataran empiris perilaku ekonomi Islam secara parsial dapat dijumpai pada sekelompok masyarakat muslim dan non muslim. Kerangka metodologis ekonomi Islam dapat dilihat dalam gambar 2 berikut ini;

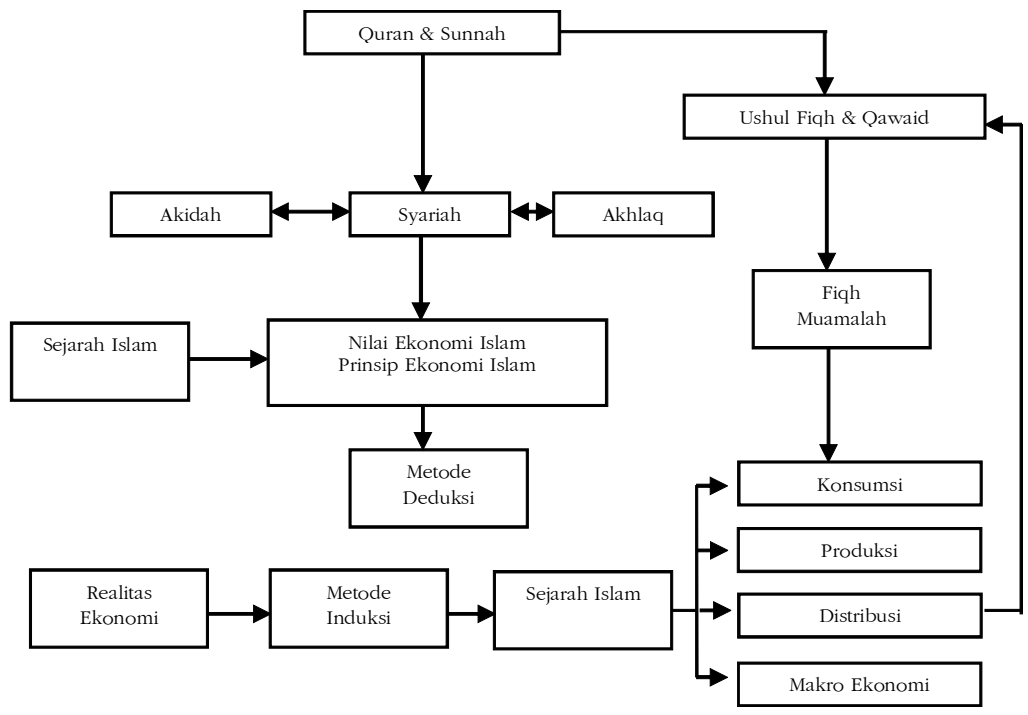

Gambar 2.

Kerangka Metodologis Ekonomi Islam (sumber: P3EI UII Yogyakarta) 
Kebenaran ilmiah dalam ekonomi Islam didasarkan atas dua hal yaitu; 1) kebenaran mutlak, hanya berasal dari wahyu (AlQuran dan Sunnah serta turunannya), 2) kebenaran relatif, bersumber dari fenomena alam semesta. Ketika kebenaran ditemukan dari wahyu, maka tetap dianggap sebagai kebenaran ilmiah meskipun tidak dijumpai fakta yang cukup mendukung. Sedangkan kebenaran yang diperoleh dari pengamatan fakta baru dapat dikatakan sebagai kebenaran ketika tidak bertentangan dengan kebenaran wahyu. Bilamana kebenaran faktual belum didukung oleh kebenaran wahyu, maka belum dapat dianggap sebagai ilmu ekonomi Islam melainkan sebagai bukti sementara dan sebatas proses untuk mendapatkan kebenaran ilmiah.

Tauhid merupakan hal yang amat fundamental terhadap segala aspek kehidupan para penganut agama Islam, tak terkecuali pada aspek pendidikan. Dalam kaitan ini banyak pakar sependapat bahwa dasar pendidikan Islam adalah tauhid, melalui dasar tauhid ini merumuskan hal-hal sebagai berikut; 1) kesatuan kehidupan; 2) kesatuan ilmu; 3) kesatuan iman dan rasio; 4) kesatuan agama; 5) kesatuan individu dan masyarakat. (Shihab dalam Fathurrohman, 2010:121)

Strategi belajar-mengajar menurut konsep Islam pada dasarnya adalah; 1) Proses belajar mengajar dilandasi dengan kewajiban yang dikaitkan dengan niat karena Allah SWT. Niat artinya menyengaja sesuatu serentak dengan melakukannya. Tempat dan pelaku niat adalah hati, namun sunnah menyertainya dengan ucapan lisan untuk membantu pernyataan sengaja yang didalam itu (Nasution dalam Fathurrohman, 2010:127).Sesuai dengan sabda Rasulullah SAW yang berbunyi "segala perbuatan akan sah menurut niatnya dan bagi setiap orang akan mendapatkan apa yang ia niatkan" (HR. Bukhari dan Muslim); 2) Konsep belajar mengajar harus dilandasi dengan niat ibadah. Dalam pengertian khusus ibadah adalah segala kegiatan yang semua ketentuannya telah ditetapkan dalam Al Qur'an dan sunnah Nabi serta tidak menerima perubahan, penambahan ataupun pengurangan. Allah SWT menciptakan manusia bukannya tanpa tujuan, akan tetapi Dia menciptakan manusia dengan tujuan tertentu yaitu untuk menyembah dan beribadah kepada-Nya. 
Sedangkan dalam pendidikan Islam anak didik memiliki kewajiban dalam proses belajar mengajar seperti: belajar dengan niat ibadah, mengurangi hal duniawi, bersikap tawadlu, menjaga pikiran, memepelajari ilmu-ilmu yang terpuji, belajar secara bertahap/berjenjang, belajar ilmu sampai tuntas, mengenal nilai-nilai ilmiah, memprioritaskan ilmu agama, mengenal nilai-nilai pragmatis bagi ilmu pengetahuan, dan yang terakhir harus tunduk pada nasihat pendidik; 4) Menciptakan komunikasi yang seimbang, komunitas yang jernih dan komunikasi yang transparant. Pada hakikatnya belajar mengajar merupakan proses komunikasi karena adanya proses penyampaian pesan dari sumber pesan melalui saluran/media dan penerima pesan yang merupakan komponen dari proses komunikasi; 5) Konsep SBM memerlukan kreatifitas, baik metodologi, didaktik desain pembelajaran sehingga tidak terpaku pada satu teori. Sesuai dengan yang dikemukakan oleh Fathurrohman yaitu Guru adalah salah seorang yang memiliki kebebasan berfikir dan bertindak, mampu untuk mengendalikan diri dalam mencari alternatif yang memungkinkan untuk mengaktualisasikan potensi kreatif yang dimilikinya, baik dalam menggunakan metodologi, ilmu didaktik dalam proses belajar mengajar sehingga tidak terpaku dalam satu teori; 6) Mendidik dengan ketauladanan yang baik. Hal ini juga diatur dalam Al-Qur'an yaitu kisah tentang qabil dan habil tentang pembunuhan; 7) Untuk memperoleh hasil yang maksimal, maka dibutuhkan pembiasaanpembiasaan karena Rasullulah sendiri telah memerintahkan kepada para pendidik agar mereka menyuruh anak-anak mereka mengerjakan shalat, taktala berumur 7 tahun; 8) Konsep-konsep SBM (konsep umum) secara lahiriyah baru akan diperlukan, yang harus diuji dengan cara kesesuaian dengan kondisi realitas dalam proses belajar mengajar dan kesesuaian dengan konsep nilai-nilai Islam; 9) Evaluasi yang baik. Menurut ajaran Islam tolak ukur keberhasilan/evaluasi bukan pengetahuan dalam arti IQ saja, tetapi keberhasilan untuk bersikap, dan berbuat (Fathurrohman, 2010:127-141); 10) proses belajar mengajar akan baik dan berhasil apabila di awali dan di akhiri dengan doa, hal ini sesuai dengan Sabda Rasullulah dan juga merupakan ibadah yang khas, yang menghubungkan hati dan pikiran manusia dengan Tuhan-Nya, yang mungkin dilakukan diawal, sewaktu atau sesudah suatu keinginan ataupun usaha dilaksanakan. 
Hasil penelitian Suyanto dkk. (2007), tentang model instruksional pendidikan anti korupsi untuk siswa SLTP dan MTS dengan pendekatan konstektual, hasilnya pendidikan anti korupsi mencakup aspek koqnitif akan memberikan bekal kemampuan dan pemahaman tentang bahaya korupsi sehingga akan memiliki komitmen yang tinggi terhadap upaya pemberantasan korupsi. Aspek afektif akan berkorelasi dengan pembentukan sikap, kesadaran dan keyakinan bahwa anti korupsi akan dialakukan dalam berbagai bidang di masyarakat. Adapun aspek psikomotor akan memberikan keterampilan dan perilaku bagaimana mengenali korupsi.

Hasil penelitian yang dilakukan Albrian Fiky Prakoso (2013), melalui penerapan model CTL dengan metode problem solving pada kajian kebutuhan manusia di kelas X TKJ di SMK Muhammadiyah 5 Kalitidu menunjukkan peningkatan yang signifikan. Peningkatan ini dapat dilihat dari data aktivitas guru pada setiap siklusnya. Pengamatan aktivitas siswa menunjukkan peningkatan yang signifikan. Hasil belajar siswa juga mengalami peningkatan pada aspek kognitif dan aspek afektif. Peningkatan ini dapat dilihat dari data hasil evaluasi pada setiap akhir siklus.

Penelitian yang lakukan Marlina (2011), melalui Model Contextual Teaching and Learning (CTL) Pada perkuliahan tata rias kecantikan wajah dan rambut untuk meningkatkan kreativitas mahasiswa, diperoleh hasil model CTL dapat meningkatkan kreativitas mahasiswa mencakup media yang digunakan untuk teori dan praktek. Media yang diperlukan untuk mata kuliah dasar rias terdiri dari media realita berupa peralatan dan bahan praktek dasar rias.

Penelitian yang dilakukan Irwandi (2009), melalui pengaruh pendekatan kontekstual dalam pembelajaran biologi melalui strategi inkuiri dan masyarakat belajar pada siswa dengan kemampuan awal berbeda terhadap hasil belajar kognitif di sma negeri kota Bengkulu, dengan hasil belajar kognitif siswa yang mendapat perlakuan pendekatan kontekstual melalui masyarakat belajar diperluas lebih baik daripada masyarakat belajar terbatas. 


\section{Metode Penelitian}

Jenis Penelitian

Berdasarkan atas tingkatannya, penelitian ini termasuk dalam jenis penelitian deskriptif. Menurut Sukandarrumidi (2006:104), jenis penelitian diskriptif bertujuan menggambarkan lebih teliti ciri-ciri sesuatu, menentukan frekuensi terjadinya sesuatu, dan prosedur penelitian harus mengikuti ketentuan-ketentuan yang baku. Sedangkan Furchan (2007:39) mengatakan bahwa penelitian deskriptif yaitu melukiskan dan menafsirkan keadaan yang ada sekarang.

Metode yang digunakan adalah metode penelitian diskriptif yaitu mendiskripsikan hasil wawancara dari dosen dan mahasiswa pendidikan ekonomi, pejabat dilingkungan jurusan Pendidikan Ekonomi dan Fakultas Ekonomi, ditabulasikan dan dianalisis. Obyek penelitian ini model pemebelajaran ekonomi syariah memlalui metode CTL pada Jurusan Pendidikan Ekonomi Fakultas Ekonomi Universitas Negeri Surabaya.

\section{Sumber Data}

Sumber data dalam penelitian ini terdiri dari data primer antara lain dari dosen dan mahasiswa pendidikan ekonomi, Ketua prodi pendidikan ekonomi, Pembantu Dekan I dan Dekan Fakultas Ekonomi, sedangkan data sekunder antara lain dari silabus mata kuliah ekonomi syari'ah, buku-buku tentang ekonomi Islam, jurnal dan hasil penelitian terdahulu tentang pembelajaran ekonomi Islam/ syari'ah.

\section{Teknik Pengumpulan Dan Teknik Analisis Data}

Teknik pengumpulan data dilakukan dengan cara deepth interview (wawancara mendalam) yang dilakukan kepada para dosen dan mahasiswa pendidikan ekonomi serta para pejabat dilingkungan Jurusan Pendidikan Ekonomi dan Fakultas Ekonomi. Sedangkan observasi dilakukan untuk mengetahui secara langsung tentang bagaimana pelaksanaan pembelajaran ekonomi syari'ah (model pembelajaran yang digunakan dan materi yang diberikan kepada mahasiswa). 
Analisis data dilakukan dengan cara menelaah semua data yang diperoleh dari berbagai sumber (primer dan sekunder), ditabulasikan dan langkah selanjutnya adalah mengadakan reduksi data yang dilakukan dengan cara membuat abstraksi. Setelah peneliti melakukan observasi dan wawancara tentang pelaksanaan pembelajaran ekonomi syari'ah di jurusan Pendidikan Ekonomi Universitas Negeri Surabaya maka peneliti memperoleh gambaran tentang pelaksanaan pembelajaran ekonomi syari'ah yang dilaksanakan pada semester tiga dan lima.Tahap selanjutnya adalah analisis data yaitu mengadakan pemeriksaan terhadap keabsahan data, mengolah data dan penafsiran data sehingga diketemukan hasil penelitian yang valid, serta temuan konsep model pembelajaran ekonomi syari'ah yang sesuai dengan kompetensi, visi dan misi pendidikan ekonomi sebagai calon tenaga kependidikan pendidikan ekonomi syari'ah.

\section{Analisis}

\section{Hasil Penelitian}

Mata kuliah ekonomi syari'ah merupakan bagian dari kurikulum di Jurusan Pendidikan Ekonomi Universitas Negeri Surabaya.Komponen silabus pembelajaran memuat sekurang-kurangnya komponen-komponen antara lain; 1) identitas silabus pembelajaran; 2) standard kompetensi; 3) kompetensi dasar; 4) materi pembelajaran; 5) kegiatan pembelajaran; 6) indikator pencapaian kompetensi; 7) penilaian; 8) alokasi waktu; dan 9) sumber belajar.

Topik ekonomi syari'ah, meliputi materi pokok/sub materi yang diberikan pada standar kompetensi pertama di Fakultas Ekonomi Universitas Negeri Surabaya yakni: 1) Sketsa historis ekonomi syaria'ah meliputi, arti, hakekat, dan ruang lingkup ekonomi syari'ah dan sejarah ekonomi syari'ah; 2) Syari'ah Islam sebagai fondasi ekonomi syaria'ah meliputi, fungsi syari'ah Islam dalam ekonomi syari'ah, hakekat hukum ekonomi syari'ah, sumber hukum ekonomi syari'ah, madzhab-madzhab fiqh dan implikasi kontemporer; 3) Sistem ekonomi syari'ah meliputi, karakteristik ekonomi syari'ah, perbedaan dasar ekonomi syari'ah dengan ekonomi konvensional, metodologi ekonomi syari'ah, kontruksi 
ideal ekonomi syari'ah; 4) Harta dalam perspektif syari'ah meliputi, pengertian dan keduduklan harta, kepemilikan, sebab-sebab kepemilikan; 5) Akad/transaksi dalam ekonomi syari'ah meliputi, pengertian dan pembentukan akad, syarat-syarat akad, dan berakhirnya akad; 6) Prinsip jual beli, bagi hasil dan pembiayaan dalam ekonomi syari'ah meliputi prinsip jual beli dalam ekonomi syari'ah, prinsip bagi hasil dalam ekonomi syari'ah, dan prinsip pembiayaan dalam ekonomi syari'ah; 7) Konsep harga dalam ekonomi syari'ah meliputi, permintaan, penawaran, harga, dan pasar; 8) Konsep pendapatan nasional dalam ekonomi syari'ah meliputi, pendapatan nasional, konsumsi, tabungan, dan investasi; 9) Keuangan publik dalam ekonomi syari'ah meliputi, zakat dan pajak; 10) Etika ekonomi syari'ah meliputi, etika produksi, konsumsi, distribusi, dan implementasi etika dalam dunia bisnis (Buku Pedoman Universitas Negeri Surabaya, 2013:211).

Sedangkan materi pokok/sub materi yang diberikan pada standar kompetensi kedua yakni: 1) Perkembangan lembaga keuangan syari'ah meliputi, sejarah lembaga keuangan syari'ah serta tantangan dan peluang; 2) Perbedaan lembaga keuangan syari'ah dan konvensional meliputi, akad dan aspek legalitas, bisnis dan usaha yang dibiayai, struktur organisasi dan lembaga penyelesai sengketa, dan perbandingan lembaga keuangan syari'ah dan konvensional; 3) Riba, bunga, dan institusi bagi hasil meliputi, pengertian serta dasar hukumnya, riba dalam perspektif agama, antara bunga serta riba, dan yang terakhir perbedaan bunga dan bagi hasil; 4) Perbankan syari'ah meliputi, pengertian serta ciri perbankan syari'ah, fungsi dan peranan, struktur bank syari'ah, dan aspek akuntansi dalam perbankan syari'ah; 5) Produk dan jasa perbankan syari'ah meliputi, pengertian, sumber dana, penyaluran dana, jasa perbankan syari'ah; 6) IDB (Islamic Development Bank) dan perkembangan bank Islam di tingkat internasional meliputi, suatu tinjauan umum, fungsi dan peranan IDB, dan yang terakhir perkembangan bank Islam di tingkat internasional; 7) BPR syari'ah meliputi, pengertian dan tujuan BPRS, ketentuan pendirian BPRS, serta kegiatan operasional BPRS dan strategi pengembangannya; 8) Pegadaian syari'ah meliputi, pengertian dan sejarah, rukun dan syarat gadai, serta operasionalisasi pegadaian syari'ah; 9) BMT 
(Baitul Mal wat Tamwil) meliputi, pengertian dan sejarah, organisasi BMT, persamaan dan perbedaannya dengan koperasi, operasionalisasi BMT; 10) Asuransi syari'ah meliputi, pengertian dan sejarah, persamaan dan perbedaan asuransi syari'ah dan konvensional, serta operasionalisasi asuransi syari'ah; 11) Pasar modal syari'ah meliputi, pengertian dan sejarah, fungsi dan karakter pasar modal syari'ah, perbedaan pasar modal syari'ah dan konvensional, obligasi syari'ah, serta reksadana syari'ah. dan yang terakhir; 12) Manajemen lembaga keuangan syari'ah meliputi, kendala dan strategi pengembangan lembaga keuangan syari'ah, pembinaan dan pengawasan lembaga keuangan syari'ah, analisi SWOT lembaga keuangan syari'ah, serta peran ulama dan umara dalam pengembangan lembaga keuangan syari'ah (Buku Pedoman Universitas Negeri Surabaya, 2013:212).

Berdasarkan pada standart kompetensi dan kompetensi dasar yang digunakan di jurusan Pendidikan EkonomiUniversitas Negeri Surabaya, dalam pelaksanaanya ternyata kurang memberikan hasil yang maksimal bagi pemahaman mahasiswa tentang ekonomi syariah. Pentingnya pengetahuan yang utuh tentang perpaduan ekonomi konvensional dan syariah sebagai pengetahuan yang digunakan dalam pemecahan permasalahan di bidang ekonomi saat ini, menuntut jurusan Pendidikan Ekonomi Universitas Negeri Surabaya mencari solusi untuk meningkatkan wawasan dan pemahaman mahasiswa tentang ekonomi syariah secara utuh.

Tabel 1

\section{Instrument Penilaian Perencanaan Pembelajaran}

\begin{tabular}{clccc}
\hline No & \multicolumn{1}{c}{ ASPEK YANG DINILAI } & KB & B & SB \\
\hline 1 & Indikator dan Tujuan Pembelajaran & - & $80 \%$ & $20 \%$ \\
2 & Kegiatan Pembelajaran & $40 \%$ & $60 \%$ & - \\
3 & Materi Ajar dan bahan ajar & $40 \%$ & $60 \%$ & - \\
\hline
\end{tabular}

Sumber: Diolah dari hasil evaluasi kegiatan pembelajaranEkonomi Syariah

Keterangan: $\mathrm{KB}=$ Kurang Baik; $\mathrm{B}=$ Baik; $\mathrm{SB}=$ Sangat Baik. 
Tabel 2

Instrument Penilaian Pelaksanaan Pembelajaran

\begin{tabular}{clrcc}
\hline No & \multicolumn{1}{c}{ ASPEK YANG DINILAI } & KB & B & SB \\
\hline I & PRAPEMBELAJARAN & $20 \%$ & $60 \%$ & $20 \%$ \\
II & KEGIATAN INTI PEMBELAJARAN & & & \\
A & Penguasaan Materi Pembelajaran & $40 \%$ & $60 \%$ & - \\
B & Pendekatan/ Strategi Pembelajaran & $60 \%$ & $40 \%$ & - \\
C & Pemanfaatan Sumber Belajar/Media & $60 \%$ & $40 \%$ & - \\
& Pembelajaran & $20 \%$ & $60 \%$ & $20 \%$ \\
D & Penggunaan Bahasa & $60 \%$ & $40 \%$ & - \\
E & Penggunaan Model Pembelajaran & $20 \%$ & $60 \%$ & $20 \%$ \\
III & PENUTUP & & \\
\hline
\end{tabular}

Sumber: Diolah dari hasil evaluasi kegiatan pembelajaran Ekonomi Syariah

Keterangan:KB= Kurang Baik; $\mathrm{B}=$ Baik; $\mathrm{SB}=$ Sangat Baik.

Tabel 3

\section{Rekapitulasi Hasil Wawancara Responden}

\begin{tabular}{clcccccc}
\hline \multirow{2}{*}{ No } & \multirow{2}{*}{ Materi } & \multicolumn{2}{c}{ KS } & S & \multicolumn{2}{c}{ SS } \\
\cline { 2 - 7 } & & D & M & D & M & D & M \\
\hline 1 & Silabus diperbaiki & $40 \%$ & - & $40 \%$ & $75 \%$ & $20 \%$ & $25 \%$ \\
2 & Materi dan sub topic diperbaiki & $40 \%$ & - & $40 \%$ & $75 \%$ & $20 \%$ & $25 \%$ \\
3 & Beban SKS ditambah & $80 \%$ & $64 \%$ & $20 \%$ & $36 \%$ & - & - \\
4 & Model Pembelajaran yang & $40 \%$ & $45 \%$ & $60 \%$ & $55 \%$ & - & - \\
& digunakan & & & & & & \\
5 & Literatur perlu ditambah & - & - & $20 \%$ & $23 \%$ & $80 \%$ & $77 \%$ \\
6 & Praktek kerja lapangan (PKL) & - & - & $40 \%$ & $32 \%$ & $60 \%$ & $68 \%$ \\
\hline
\end{tabular}

Sumber: Diolah dari hasil wawancara dengan responden

Keterangan: $\mathrm{KS}=$ Kurang setuju; $\mathrm{S}=\mathrm{Setuju}$; $\mathrm{S}=$ Sangat setuju. $\mathrm{D}=$ Dosen; $M=$ Mahasiswa.

Ekonomi saat ini dipandang sebagai disiplin sosial maupun sains yang tak pernah berhenti berevolusi. Pada sisi sosial, fenomena globalisasi membuat relasi-relasi antarentitas ekonomi semakin tak 
terbatas. Sebaliknya, pada sisi sains modernisasi telah menghasilkan penelitian-penelitian yang baru sebagai pengganti penelitian sebelumnya. Di sisi lain nilai dan norma, yaitu variabel yang sempat termarjinalkan dari aktivitas ekonomi mulai diangkat kembali. Hal ini dapat dilihat dari perkembangan ilmu ekonomi yaitu ilmu ekonomi dari barat (konvensional) yang mengusung hipotesis dari Aquinas (1225-1274) atau Max weber (1905) dengan semangat relijius Kristen (Achsien, 2000) yang pada perkembangannya saat ini dianggap masih memiliki dua permasalahan besar, yaitu kemiskinan dan pengangguran (Mankiw, 2003). Kedua permasalahan tersebut mengakibatkan perkembangan ilmu ekonomi yaitu ekonomi Islam yang dianggap sebagai jalan keluar dari permasalahan yang timbul karena inti dalam Islam, ekonomi bukanlah segala-galanya. Akan tetapi ekonomi hanya sempurna jika akidah, syari'ah, dan akhlak telah tersintesis sempurna, yang tak menyimpang dari AlQur'an dan Al-Hadist (dalam Syafii, 2009:33-35).

Selanjutnya terdapat fenomena yang cukup mengkhawatirkan yaitu metode sosialisasi ekonomi Islam itu sendiri. Secara garis besar, sosialisasi ekonomi Islam kepada komunitas awam lebih banyak menggunakan sarana seminar, pelatihan, dan diskusi panel. Padahal pemahaman yang holistik mengenai suatu hal tidak dapat dibangun secara instan (Syafii, 2009:36). Maka diperlukan pengembangan yang lebih lanjut untuk sosialisasi ekonomi Islam. Mengacu dari objek filsafat, baik filsafat Islam maupun filsafat ilmu bila ditinjau secara materia terdapat kesamaan dan berbeda bila secara forma. Adapun objek kajian filsafat Islam itu sendiri mencakup Tuhan, alam, dan manusia yang bersumber kepada Al-Qur'an, Al-Hadis, dan akal.

Berdasarkan doktrin monontheisme atau Keesaan Allah, Allah adalah pencipta alam semesta yang tidak berawal atau (qadim), tidak berakhir (baqa), tidak berubah, maha tahu, maha kuasa, satu-satunya yang disembah. Oleh karena itu tidak ada yang menyerupainya dalam kodrat atau sifat-sifatnya, dosa terbesar yang tidak mungkin diampuni adalah dosa penyekutuan terhadap Allah (syirik). Menurut Shaykh Kuala dalam Abdullah et al., (2009: 184) manusia prima dalam Islam adalah manusia yang senantiasa mendekatkan diri kepada Allah SWT. Akidah dan makrifatullah 
adalah asas paling utama dalam usaha mengesakan Allah SWT. Dan untukmengukuhkan suatu keyakinan (akidah) di dalam Islam, maka diperlukan pendekatan munasabah dari nas-nas Islam yang qat'iy (kuat).

Masalah penyelarasan antara filsafat dan agama tidak mungkin bertentangan dengan agama karena kedua-duanya bersumber pada hakekat terakhir yang sama, dan apabila ada ketidakserasian diperlukan refleksi yang lebih mendalam atau tafsiran baru. Apabila kontradiksinya tidak dapat dihilangkan juga, timbul perbedaan pendapat tentang apakah akal pikiran atau iman yang harus diutamakan. Dalam surat Annisa 4: 29, "Hai orang-orang yang beriman, janganlah kamu saling memakan harta sesamamu dengan jalan yang bathil, kecuali dengan jalan perniagaan yang berlaku dengan suka sama suka diantara kamu. Dan janganlah kamu membunuh dirimu. Dan sesungguhnya Allah Maha Penyayang kepadamu".

Sebagai jawaban pemecahan dari fenomena di atas, Fakultas Ekonomi Universitas Negeri Surabaya mulai mengembangkan bidang keilmuannya dengan mengikuti perkembangan ilmu ekonomi syari'ah. Hal tersebut dapat dilihat dari adanya mata kuliah ekonomi syari'ah, dimana mata kuliah tersebut diharapkan dapat memberikan pemahaman, wawasan, dan perkembangan ekonomi syari'ah secara lebih mendalam.

Pada mata kuliah ekonomi syari'ah tidak hanya mempelajari ekonomi syari'ah secara sendiri-sendiri akan tetapi pembelajaran ekonomi tersebut, saling berintegrasi dengan ekonomi konvensional sehingga mahasiswa memiliki pengetahuan dan wawasan yang utuh mengenai perkembangan ilmu ekonomi. Sehingga apabila mahasiswa telah terjun menjadi seorang guru, nantinya wawasan yang dimiliki tidak hanya terbatas pada ilmu ekonomi barat (konvensional) akan tetapi ilmu ekonomi secara utuh yang dapat memberikan solusi/jawaban dari semua permasalahan yang timbul secara lebih syar'i.

Berdasarkan pemaparan di atas, mata kuliah ekonomi syari'ah baru diberikan pada semester 3 dan 5 . Oleh karena itu, solusi yang dapat diberikan yaitu adanya pembenahan model pembelajaran agar pemahaman mahasiswa lebih mendalam dan dapat memahami 
secara utuh. Selain itu, model pembelajaran dalam mata kuliah ekonomi syari'ah juga perlu dikembangkan. Salah satu contoh model pembelajaran yang dapat digunakan dalam pembelajaran ekonomi syari'ah yaitu model pembelajaran CTL. Model pembelajaran ini lebih cenderung mengajak mahasiswa untuk berfikir kritis dan kreatif karena mahasiswa harus menghubungkan isi materi dengan konteks kehidupan nyata dan mencari solusi yang terbaik untuk memecahkan fenomena tersebut.

Model pembelajaran CTL dapat mewujudkan kompetensi mahasiswa yang harus dimiliki sesuai pada standard kompetensi karena dalam kegiatan pembelajaran mahasiswa dituntut untuk mengkaitkan/menghubungkan dengan fenomena yang terjadi di masyarakat saat ini. Kompetensi pertama antara lain; bagaimana memahami hakekat, fondasi, filosofi, sumber hukum, sistem, harta, transaksi, jual beli, bagi hasil dan etika ekonomi syari'ah. Kompetensi kedua antara lain; lembaga keuangan, riba bunga dan bagi hasil, perBankan, pegadaian, BMT dan pasar modal. Karena masalahmasalah perekonomian saat ini semakin kompleks, oleh karena itu mahasiswa perlu memahami secara utuh pembelajaran ekonomi syari'ah dengan cara menggunakan model pembelajaran CTL artinya; perlu pemahaman secara kognitif, afektif dan psykomotor secara jelas dan benar.

Atas dasar kompetensi yang harus dimiliki oleh mahasiswa dan fenomena yang terjadi dimayarakat maka harus dapat mencari alternative pemecahan tentang fenomena yang hanya merujuk pada aturan-aturan, system, kebijakan-kebijakan yang berlaku ekonomi konvensional ternyata tidak mampu menghadapi krisis, kemiskinan, keadilan, kesejahteraan, kejujuran, keterbukaan, kemakmuran rakyat yang merata, harmonisasi dan kedamaian dalam hidup, mewujudkan peri kehidupan ekonomi umat manusia yang makmur dan selalu dalam taraf yang lebih maju guna memenuhi kebutuhan jasmani, rohani, serta kebutuhan spiritual dalam rangka menumbuhkan taraf kesejahteraan duniawi maupun ukhrowi secara serasi dan seimbang, adil dan merata, secara jujur dan terarah, selalu meningkatkan taraf keadilan dan pemerataannya, mengindari dari gangguan inflasi dan depresi atau stagnasi, bersatu dan damai, dalam suasana kekeluargaan sesama umat, menghilangkan nafsu untuk 
menguasai dan menumpuk harta, menumbuhkan sikap kebersamaan (solidaritas), tidak menimbulkan kerusakan di bumi, menjaga kelestarian alam baik alam fisik, kultural, sosial maupun spiritual keagamaan, serta mandiri tanpa adanya ketergantungan yang berlebihan dari kelompok-kelompok masyarakat lain.

Alternative yang sekarang muncul untuk mengahadapi fenomena tersebut adalah ekonomi syari'ah. Menurut Mustafa (2006:17), berpendapat bahwa ekonomi Syari'ah merupakan ilmu ekonomi positif dan normative, karena keduanya saling berhubungan dalam membentuk perekonomian yang baik dalam evaluasinya nanti.

Bila ditampilkan dalam tabel dapat dilihat perbandingan sistem perekonomian komunis, kapitalis, dan Islam seperti tabel 4 di bawah ini;

\section{Tabel 4}

\section{Tujuan Sistem Perekonomian}

\begin{tabular}{|c|c|c|c|c|}
\hline \multirow{2}{*}{ No } & \multirow{2}{*}{ Uraian ringkas Tujuan } & \multicolumn{3}{|c|}{ Sistem Ekonomi } \\
\hline & & Komunis & Kapitalis & Islam \\
\hline 1. & $\begin{array}{l}\text { Kemakmuran \& } \\
\text { kesejahteraan }\end{array}$ & Duniawi & Duniawi & $\begin{array}{l}\text { Duniawi \& } \\
\text { ukhrowi }\end{array}$ \\
\hline 2. & Adil dan merata & & Tid: & Merata dan \\
\hline 3. & \& kemaj & Stabil $\mathrm{m}$ & Tidak stab & Stabil dan $\mathrm{n}$ \\
\hline 4. & Serasi, damai, bersatu & Tidak & Tidak & Ya \\
\hline 5. & Merdeka & Tidak & Merdeka & Merdeka \\
\hline 6. & Kelestarian alam & Tidak & Tidak & $\mathrm{Ya}$ \\
\hline 7. & Mandiri & $\mathrm{Ya}$ & Tidak & $\mathrm{Ya}$ \\
\hline
\end{tabular}

Sumber: Dirjen Pembinaan kelembagaan Agama Islam

Berdasarkan tabel 4 di atas, ekonomi Islam memiliki sikap yang moderat (wasthiyyah). Artinya tidak menzalimi kaum lemah sebagaimana terjadi pada masyarakat kapitalis, akan tetapi juga tidak menzalimi hak individu dan kelompok-kelompok yang memiliki modal sebagaimana ada pada sistem komunis. Jadi, ekonomi Islam berada pada posisi tengah dan seimbang antara keduanya. Dengan kata lain eksis dan berdampak positif bagi kelangsungan hidup masyarakat dunia dan sustainabilitas alam semesta. 


\section{Kesimpulan}

Merujuk dari pembelajaran ekonomi syari'ah di jurusan Pendidikan Ekonomi Universitas Negeri Surabayamasih menggunakan pengajaran langsung dan bergantung pada kemampuan dosen, sehingga belum dapat membentuk pemahaman kepada mahasiswa memiliki karakteristik mewujudkan suatu komunitas yang memiliki pemikiran dan sikap kreatif, cerdas, berwawasan serta memiliki pengetahuan dalam mengahadapi permasalahan ekonomi secara utuh dengan lebih syar'i yang tetap bertumpu pada jiwa nasionalisme dan budaya bangsa Indonesia. Disamping itu adanya hambatan yang dapat mempengaruhi pembelajaran antara lain kemampuan dasar dan keyakinan yang dimiliki oleh mahasiswa heterogen, kurangnya perhatian dan minat dalam kegiatan pembelajaran, kegiatan pembelajaran berjalan satu arah dan pasif, dosen masih disibukkan dengan pembuatan media untuk ditransformasikan kepada mahasiswa.

Dengan menggunakan model pembelajaranContectual Teaching Learning (CTL) diharapkan dosen dalam menyampaikan materi perkuliahan lebih mudah memberikan berbagai penjelasan, mahasiswa diberikan kesempatan untuk memberikan tanggapan secara individual dan kelompok, kemudian diminta membuat laporan secara tertulis dan menyampaikan dalam diskusi kelompok dan kelas. Disamping itu perlu adanya tugas individual dan kelompok untuk mengetahui secara langsung fenomena yang terjadi dan alternatife pemecahan yang dilakukan oleh masyarakat. Hasil berbagai pendapat/pandangan mahasiswa merupakan keputusan akhir pembelajaran, dan perbedaan pendapat terhadap persoalan yang dibahas adalah wajar-wajar saja karena perbedaan sisi pandang, dasar pemikiran, dan semuanya untuk kepentingan bersama.

\section{Daftar Pustaka}

Abdullah, M. S. C, Ahmad, S, dan Jaafar, M. F. 2009. Panduan Individu Menuju Ke Jalan Allah. Malaysia. Institut Alam dan Tamadun Melayu Universiti Kebangsaan Malaysia.

Departemen Agama RI. Al-Qur'an dan terjemahannya. Dirjen Pembinaan Kelembagaan Agama Islam RI 2007. 
Fathurrahman, Pupuh dan Sutikno, Sobi. 2010. Strategi Belajar Mengajar Melalui Penanaman Konsep Umum \& Konsep Islami.Bandung : PT. Refika Aditama.

Furchan, Arief. 2007. Pengantar Penyelidikan Dalam Pendidikan.Yogyakarta : Pustaka Pelajar.

Irwandi, 2009, Pengaruh Pendekatan Kontekstual dalam Pembelajaran Biologi melalui Strategi Inkuiri dan Masyarakat Belajar pada Siswa dengan Kemampuan Awal Berbeda terhadap Hasil Belajar Kognitif di SMA Negeri Kota Bengkulu, Jurnal Kependidikan Triadik, Volume 12, No. 1 : 33-43, April.

Marlina dkk, 2011, Model Contextual Teaching And Learning (Ctl) Pada Perkuliahan Dasar Rias (Tata Kecantikan Wajah Dan Rambut) Untuk Meningkatkan Kreativitas Mahasiswa, Jurnal Penelitian Pendidikan, Vol. 12 No. 1 : 13-23, April.

Mustafa Edwin dkk.2006.Pengenalan Eksklusif Ekonomi Syari'ah, Jakarta Kencana Predana Media Group

Nur, Mohamad. 2011. Model Pembelajaran Langsung. Surabaya : Pusat Sains dan matematika Sekolah.Universitas Negeri Surabaya.

P3EI. 2011. Ekonomi Islam. Yogyakarta: PT. RajaGrafindo Persada. Pendidikan Ekonomi, Universitas Negeri Surabaya. 2009. Strategi Belajar Mengajar. Surabaya: Universitas Negeri Surabaya University Press.

Prakoso, Albrian Fiky, 2013, Penerapan Model CTL Dengan Metode Problem Solving Dalam Meningkatkan Hasil Belajar Kajian Kebutuhan Manusia Siswa Smk Muhammadiyah 5 Kalitidu, Jurnal Pendidikan Ekonomi, Vol 6, No. 1 : 27-47, Juni.

Riyanto, H. Yatim. 2009. Paradigma Baru Pembelajaran. Jakarta: Kencana Prenada Media Group.

Sudarsono, Heri. 2002. Konsep Ekonomi Islam Suatu Pengantar. Yogyakarta : Ekonisia.

Sukandarrumidi. 2006. Metodelogi Penelitian. Jogjakarta : Gadjah Mada University Press.

Supriyadi, Dedi. 2010. Pengantar Filsafat Islam. Bandung: CV. Pustaka Setia. 
Suyanto, totok Dkk., 2007, Model Instruksional Pendidikan anti korupsi untuk siswa SLTP dan Mts dengan pendekatan kontekstual, kumpulan hasil penelitian biaya dikti, LPPM Unesa.

Syafii, Muhammad. 2009. Ekonomi Islam Substantif. Bogor: Lembaga Penelitian \& Pemberdayaan Masyarakat.

Trianto.2009. Mendesain Model Pembelajaran Inovatif-Progresif. Jakarta: Prenada Media Group.

Unipres Unesa. 2013. Buku Pedoman Unesa.

Yayat, sujatna, 2012, Efektifitas Pembelajaran Ekonomi Islam di STIE Ahmad Dahlan Jakarta, Jurnal Liquidity vol.1,no.2 : 167-174, juli-desember 